\title{
Removal of color and turbidity in sugarcane juice treated by electrocoagulation with aluminum electrodes
}

\author{
Remoção de cor e turbidez de caldo de cana-de-açúcar por \\ eletrocoagulação utilizando eletrodos de alumínio
}

\author{
Felipe Iwagaki Braga Ogando', Taís Xastre ${ }^{2}$, Eduardo Simões², Claudio Lima de Aguiar ${ }^{3 *}$ (1) \\ ${ }^{1}$ Universidade de São Paulo (USP), Agro-Industry, Food and Nutrition Department, Piracicaba/SP - Brasil \\ ${ }^{2}$ Metrohm Brasil Instrumentação Analítica Ltda, Analytical Division, São Paulo/SP - Brasil \\ ${ }^{3}$ Universidade de São Paulo (USP), Luiz de Queiroz College of Agriculture, Agro-Industry, Food and Nutrition \\ Department, Hugot Sugar Technology Laboratory, Piracicaba/SP - Brasil
}

*Corresponding author: Claudio L. Aguiar, Universidade de São Paulo (USP), Luiz de Queiroz College of Agriculture, Agro-Industry, Food and Nutrition Department, Hugot Sugar Technology Laboratory, Av. Pádua Dias, 11, CEP: 13418-900, Piracicaba/SP - Brasil, e-mail: claguiar@usp.br

Cite as: Ogando, F. I. B., Xastre, T., Simões, E., \& Aguiar, C. L. (2021). Removal of color and turbidity in sugarcane juice treated by electrocoagulation with aluminum electrodes. Brazilian Journal of Food Technology, 24, e2020236. https://doi.org/10.1590/1981-6723.23620

\begin{abstract}
The liming $\left(\mathrm{Ca}(\mathrm{OH})_{2}\right.$ addition) and sulfitation ( $\mathrm{HSO}_{3}{ }^{-}$addition) is the conventional treatment for purification of sugarcane juice $(\mathrm{SCJ})$ in sugar cane mills to crystal sugar production. Although, the sulfite has been associated to human health problems, this industrial step kept untouchable or few studies have been made to change this scenery. This work aimed to evaluate the variables which influence the electrocoagulation performance on the SCJ purification as a sulfur-free crystal sugar process. A fractional factorial design with the surface response methodology was used to evaluate the influence of voltage, $\mathrm{pH}$, soluble solids total (Brix), temperature and distance between the electrodes in the electrocoagulation process. The outputs were turbidity, juice color, sucrose contents (as pol\%juice) and Reducing Sugars (RS). Residual aluminum was analyzed by voltammetry to control de aluminum releasing into the treated juice. The electrocoagulation reduced color and turbidity, in special at low pH (2.5), highest voltage $(25 \mathrm{~V})$ and minimal distance of electrode $(1.0 \mathrm{~cm})$. Although in this conditions, sucrose was converted into RS indicating partial hydrolysis. In this work, the most part of residual aluminum went to floated and precipitated phases $(76.8 \%$ and $18.1 \%$, respectively), whereas only $5.1 \%$ remained in the SCJ clarified. Electrocoagulation/electroflotation proved to be a potential technique as a substitute for sulfitation in SJC treatment, which ensures the production of safe food for humans.
\end{abstract}

Keywords: Sucrose; Sulfitation; Clarification; Coagulation; Aluminum; Voltammetry.

\section{Resumo}

A caleagem [adição de $\mathrm{Ca}(\mathrm{OH})_{2}$ ] e a sulfitação (adição de $\mathrm{HSO}_{3}{ }^{-}$) são etapas do tratamento convencional do caldo de cana (CCA) em usinas para a produção de açúcar cristal. Embora a geração de sulfito esteja 
associada a problemas de saúde humana, essa etapa industrial manteve-se intocável, sendo que poucos estudos foram feitos para alterar esse cenário. Este trabalho teve como objetivo avaliar as variáveis que influenciam o desempenho da eletrocoagulação na purificação de CCA como um processo alternativo à produção de açúcar cristal sem uso de enxofre. Um planejamento fatorial fracionário com a metodologia de resposta de superfície foi utilizado para avaliar a influência da tensão, do $\mathrm{pH}$, dos sólidos solúveis totais (Brix), da temperatura e da distância entre os eletrodos no processo de eletrocoagulação do caldo de cana. As respostas avaliadas foram turbidez, cor do caldo, teor aparente de sacarose (como pol\%caldo) e açúcares redutores (AR). O alumínio residual foi analisado por voltametria, para avaliar a liberação de alumínio no caldo tratado. A eletrocoagulação reduziu a cor e a turbidez, em especial em pH baixo $(=2,5)$, tensão mais alta $(=25 \mathrm{~V})$ e distância mínima do eletrodo $(=1,0 \mathrm{~cm})$. Verificou-se, contudo, que, nessas condições, a sacarose foi parcialmente convertida em $A R$, indicando hidrólise. Neste trabalho, a maior parte do alumínio residual foi para as fases flotada e precipitada (76,8\% e 18,1\%, respectivamente), enquanto apenas $5,1 \%$ permaneceram no CCA clarificado. A eletrocoagulação/eletroflotação mostrou-se uma técnica potencial como substituto à sulfitação no tratamento de CCA, o que garante a produção de alimentos seguros para a população.

Palavras-chave: Sacarose; Sulfitação; Clarificação; Coagulação; Alumínio; Voltametria.

\section{Introduction}

The crystal sugar manufacturing from sugarcane is divided into extraction and treatment of the sugarcane juice (SCJ); evaporation of clarified juice; crystallization, centrifugation, drying and bagging of the sucrose (crystal sugar). The raw SCJ treatment is compound for sieving, sulfitation and liming of SCJ; heating and flashing to remove the gas; and decantation of impurities (non-sugars like proteins, waxes, colloids, etc.) from the SCJ. This set of techniques aims: (I) to form flocs that suspend organic and inorganic impurities; (II) to promote conditions of temperature, $\mathrm{pH}$ and ion concentration that avoid sucrose loss by hydrolysis or Maillard reaction and/or caramelization; (III) to eliminate microorganisms that are harmful to the process and quality of sugar (Rein, 2007). However, the use of sulfur (or sulfite) in the cane juice clarifying have some limitations, for example, sucrose loss by the low $\mathrm{pH}$ (3.8 to 4.3) and the low solubility of sulfur dioxide gas in the SCJ; environmental damage related to sulfur burning; and threats to human health in consequence of sulfur (reduced chemical species) residues in the crystal sugar. Hence, there are trade barriers to white sugar, and consequently, Brazil exports in its majority the Very High Polarization (VHP) sugar type (raw sugar without sulfitation and with lower added value) (Machado and Toledo 2006; Machado et al., 2008; Morilla et al., 2015a, 2015b).

These conditions have intensified the search for alternative methods of cane juice treatment without sulfur use, such as hydrogen peroxide (Campiol et al., 2019; Sartori et al., 2017a; Mandro et al., 2017; Sartori et al., 2015; Nguyen \& Doherty, 2011), ozone (Azevedo et al., 2019; Sartori et al., 2019; Rodrigues et al., 2018; Sartori et al., 2017b; Silva et al., 2015), radiation (Lima et al., 2016), ceramic membrane filtration (Shi et al., 2021; Vu et al., 2020; Akhtar et al., 2020a; Shi et al., 2019; Li et al., 2018; Nogueira \& Venturini-Filho, 2007) and thermosonication (Medeiros et al., 2021). Electrocoagulation emerges as alternative clarifying technology to cane mills as showed previously by Ogando et al. (2019). According to them, electrocoagulation was capable to reduce turbidity and color in $99.9 \%$ and $70 \%$, respectively. However, it is also important to monitor sucrose concentration throughout the process once the electrocoagulation process causes aggressive and non-selective decomposition (Moradi \& Moussavi, 2019; Kobya et al., 2017; Torres-Sánchez et al., 2014; Manenti et al., 2015). Electrocoagulation process is the generation of coagulants species from electrodes material (anode) in the own reaction site by electric current applied (Akhtar et al., 2020b). According to $\mathrm{pH}$, the metal released from the anode hydrolyses to form coagulant species capable of removing impurities (Rafiee et al., 2020; Syaichurrozi et al., 2020; Hashim et al., 2019). Meanwhile, 
in cathode occurs the deposition of impurities and reduction of water to $\mathrm{H}_{2}$ (Hakizimana et al., 2017). For instance, electrocoagulation processes with iron or aluminum electrodes have been shown high efficiency in carbon, nitrogen and turbidity removal (Garcia-Segura et al., 2017; Kyzas \& Matis, 2016; Kushwaha et al., 2010; Tchamango et al., 2010; Şengil \& Özacar, 2006). The preference for aluminum electrode instead of iron was due higher capacity of impurity adsorption by aluminum hydroxides and oxides formed during the process (Emamjomeh \& Sivakumar, 2009; Souza et al., 2016), lower energy consumption per carbon removal, and lower sacrifice electrode consumption (Asha \& Kumar, 2016). The concerns about the use of aluminum are related to residues of $\mathrm{Al}^{3+}$ in the final product. $\mathrm{Al}^{3+}$ is harmful for human health and should be constantly monitored (Emamjomeh \& Sivakumar, 2009). High quantities of aluminum ingested are distributed in all human tissues, accumulating mainly in bones and even inside the brain. There are suspicious that the metal can be associated to DNA mutations, carcinogenic problems and neurodegenerative diseases like Alzheimer's disease (Liaquat et al., 2019; Yousef et al., 2019; Colomina \& Peris-Sampedro, 2017). Consequently, Food and Agriculture Organization (FAO) of the United Nations defined an ingestion limit of $1 \mathrm{mg}$ of aluminum per $\mathrm{kg}$ of body weight per week (Aguilar et al., 2008; Stahl et al., 2011).

In the same reasoning, the use of sulfur in treatment of raw materials in the food industries (when in high concentrations) also presents restrictions on the impacts on human health (Han et al., 2020; D'Amore et al., 2020). In this sense, the understanding of the processes involved the electrocoagulation with aluminum electrodes would allow the definition of mechanisms for its removal below the limits of toxicity, as it is done for the sulfur with the use of the liming. Thus, this work aimed to evaluate the electrocoagulation of raw SCJ extracted from healthy sugarcane, using aluminum electrodes. The variables (voltage, electrode distance, $\mathrm{pH}$, Brix (soluble solids content) and temperature) were monitored to assess the reduction in SCJ color and turbidity and also considering these conditions to avoid sucrose degradation and to predict the accumulation of aluminum residues at clarified juice.

\section{Materials and methods}

\subsection{Plant material and extraction of sugarcane juice}

Healthy canes were disintegrated in forage and then pressed at $250 \mathrm{kgf} \mathrm{cm}^{-2}$ per 1 min to obtain the raw SCJ. This process simulates the milling in sugar mills according to Consecana (Conselho de Produtores de Cana-de-Açúcar, Açúcar e Etanol do Estado de São Paulo, 2015). Then, SCJ was filtered through 200 mesh sieves to remove inorganic impurities and fiber from cane plants, and the juice was stocked at $-18{ }^{\circ} \mathrm{C}$ until the tests was performed. SCJ was characterized and presented soluble solids contents of $19^{\circ}$ Brix (total soluble solids), turbidity of 1,206 NTU (Nephelometric Turbidity Unit), $\mathrm{pH} 5.34$, conductivity of $4.87 \mathrm{mS} \mathrm{cm} \mathrm{cm}^{-1}, 4.89 \mathrm{~g} \mathrm{~L}^{-1}$ of reducing sugars ([glucose]+[fructose] $=\mathrm{RS}$ ), pol\%juice of 16.84\% (apparent sucrose content) and ICUMSA color of 6494.2 IU (ICUMSA units). The procedures to analysis the cane juice samples will be presented in the sequence and all of them followed the official methods from ICUMSA and Consecana.

\subsection{Treatment of sugarcane juice by electrocoagulation with aluminum electrodes}

Electrocoagulation process was carried out using a jacket reactor with $400-\mathrm{mL}$ capacity. It was coupled to a thermostatic water-bath, where a bomb Pump-King (HP 1/30, 1,550 rpm, 60 cycles) transferred water from water-bath to the reactor. The electrodes consisted of two aluminum sheets $(15 \times 3.5 \times 2 \mathrm{~cm})$, as it was connected to a transformer (Superior Electric, Connecticut, USA) which controls the voltage during the assays. The schematic reactor was shown in Figure 1. 


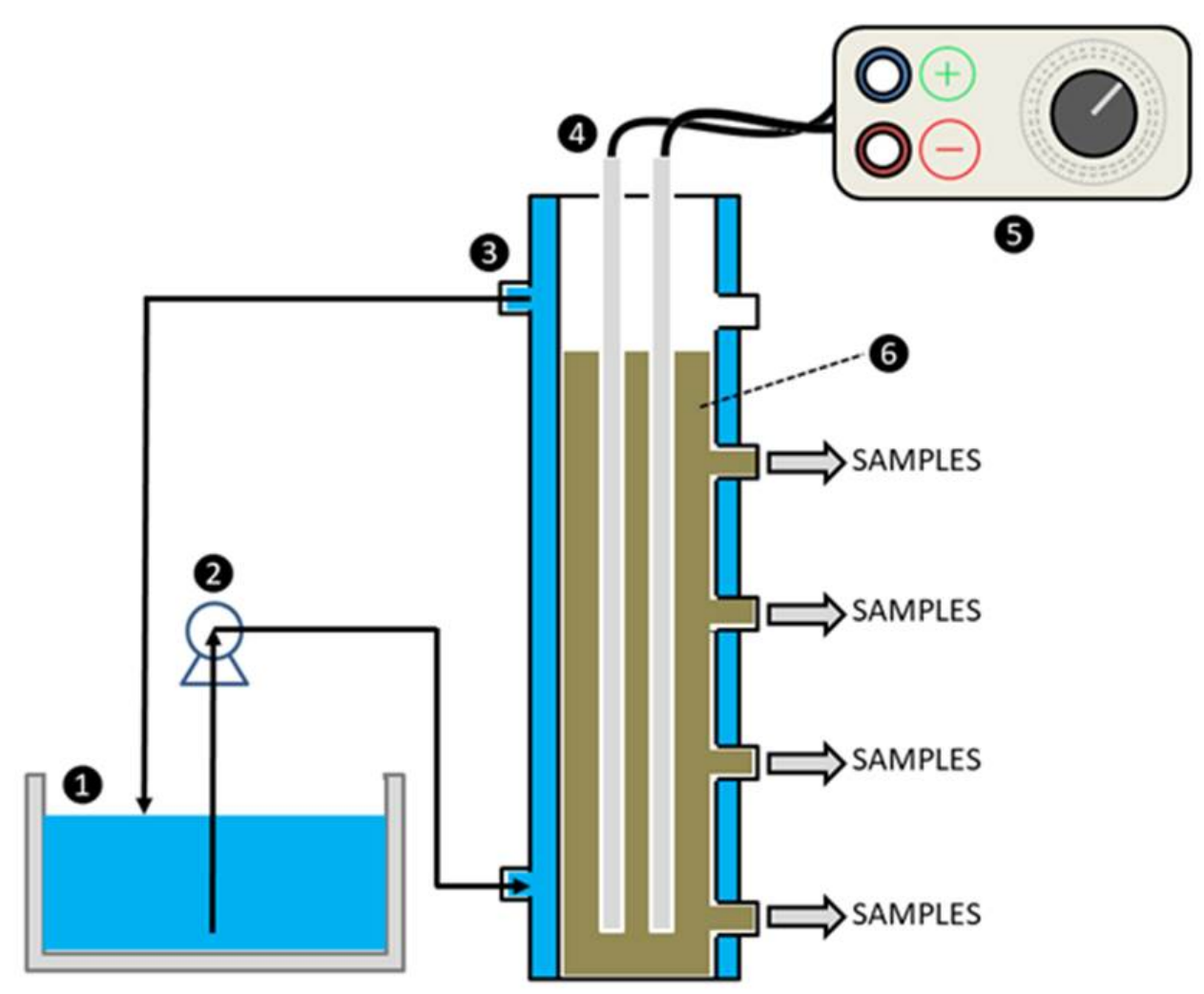

Figure 1. Schematic diagram of reactor for treatment of sugarcane juice by electrocoagulation with aluminum electrodes. 1. Water bath. 2. Bomb pump (Model King HP 1/30, 1,550 rpm, 60 cycles). 3. Jacket reactor with 400-mL capacity. 4. Two aluminum sheets $(15 \times 3.5 \times 2 \mathrm{~cm})$. 5. Transformer (model Superior Electric) to adjust the voltage. 6 . Sugarcane juice.

The fractional factorial $2^{4-1}$ (20 runs) was selected as multivariate experimental design. The factors were as following: $\mathrm{pH}\left(\mathrm{X}_{1}\right)$; temperature $\left(\mathrm{X}_{2}\right)$; voltage $\left(\mathrm{X}_{3}\right)$; electrodes distance (distance; $\left.\mathrm{X}_{4}\right)$; and total soluble solids $\left(\mathrm{Brix} ; \mathrm{X}_{5}\right)$, as shown in Table 1 . The factors were performed in large range, once there are not enough references for the use of electrocoagulation in SCJ treatment. The fractional design allowed evaluating the influence of the factors isolated, but also the double interactions between voltage and soluble solids (voltage*Brix); $\mathrm{pH}$ and voltage ( $\mathrm{pH}^{*}$ voltage); voltage and distance of electrodes (voltage*distance); $\mathrm{pH}$ and distance of electrode ( $\mathrm{pH}^{*}$ distance); distance of electrode and soluble solids (distance*Brix); temperature and voltage (temperature*voltage); temperature and distance of electrode (temperature*distance) as well the triple interactions between temperature, voltage and distance of electrode (temperature*voltage*distance); voltage, distance of electrodes and soluble solids (voltage*distance* Brix); $\mathrm{pH}$, temperature and soluble solids $\left(\mathrm{pH}^{*}\right.$ temperature*Brix); and $\mathrm{pH}$, voltage and distance of electrodes ( $\mathrm{pH}^{*}$ voltage*distance).

Table 1. Coded and real values of parameters analyzed during fractional factorial.

\begin{tabular}{ccccc}
\hline \multirow{2}{*}{ Factors } & Parameters & \multicolumn{3}{c}{ Coded values } \\
\cline { 3 - 5 } & & $\mathbf{- 1}$ & $\mathbf{0}$ & $\mathbf{+ 1}$ \\
\hline$X_{1}$ & $\mathrm{pH}$ & 2.5 & 6 & 9.5 \\
\hline$X_{2}$ & Temperature $\left({ }^{\circ} \mathrm{C}\right)$ & 25 & 47.5 & 70 \\
\hline$X_{3}$ & Voltage $(\mathrm{V})$ & 15 & 20 & 25 \\
\hline$X_{4}$ & Total soluble solid $($ Brix $)$ & 5 & 10 & 15 \\
\hline$X_{5}$ & Electrodes distance $(\mathrm{cm})$ & 1 & 2.5 & 4 \\
\hline
\end{tabular}

The column values $-1,0 \mathrm{e}+1$ are minimum, central and maximum points, respectively. 
The outputs $\left(Y_{1}, Y_{2}, Y_{3}, Y_{4}\right)$ evaluated were: International Commission for Uniform Methods of Sugar Analysis (ICUMSA) color and it expresses the SCJ color index; International Commission for Uniform Methods of Sugar Analysis, 2011), turbidity (direct reading; Tecnopon turbidimeter Mod. TB1000), Reducing Sugars (RS) (Miller, 1959) and pol\%juice (Conselho de Produtores de Cana-de-Açúcar, Açúcar e Etanol do Estado de São Paulo, 2015). The efficiency was measured according to the reduction of turbidity and ICUMSA color and no decomposition of sucrose and no increase of RS (Table 2). All results were calculated as a function of initial Brix so that the dilution effect would be undone. Analysis of Variance (ANOVA) and regression (significance level of 5\%) was made by statistic package MiniTab17 trial version (2021).

Table 2. Fractional factorial design $2^{4-1}$ with the combination of parameters: $\mathrm{pH}\left(X_{1}\right)$, temperature $\left(X_{2}\right)$, voltage $\left(X_{3}\right)$ and electrodes distance $\left(X_{4}\right)$ and its outputs turbidity $\left(Y_{1}\right)$, ICUMSA color $\left(Y_{2}\right)$, pol\% juice $\left(Y_{3}\right)$ and reducing sugars $\left(Y_{4}\right)$.

\begin{tabular}{|c|c|c|c|c|c|c|c|c|c|}
\hline Runs & $\mathrm{pH} X_{1}$ & $\begin{array}{l}\text { Temperature } \\
\left({ }^{\circ} \mathrm{C}\right) X_{2}\end{array}$ & $\begin{array}{c}\text { Voltage } \\
\text { (V) } X_{3}\end{array}$ & $\begin{array}{l}\text { Distance } \\
(\mathrm{cm}) X_{4}\end{array}$ & $\operatorname{Brix} X_{5}$ & $\begin{array}{l}\text { Turbidity } \\
\text { (NTU) } Y_{1}\end{array}$ & $\begin{array}{c}\text { Color } \\
\text { ICUMSA } Y_{2}\end{array}$ & $\begin{array}{l}\text { Pol } \\
(\%) Y_{3}\end{array}$ & $\begin{array}{c}\text { Reducing } \\
\text { sugar }\left(g_{\mathbf{L}^{-1}}\right) \\
Y_{4}\end{array}$ \\
\hline 1 & $-1(2.5)$ & $-1(25)$ & $-1(15)$ & $-1(1)$ & $-1(5)$ & 109.93 & 0.21 & 0.87 & 768.16 \\
\hline 2 & $+1(9.5)$ & $-1(25)$ & $-1(15)$ & $-1(1)$ & $+1(15)$ & 73.40 & 0.26 & 0.83 & 457.09 \\
\hline 3 & $-1(2.5)$ & $+1(70)$ & $-1(15)$ & $-1(1)$ & $+1(15)$ & 45.81 & 0.96 & 1.07 & 282.66 \\
\hline 4 & $+1(9.5)$ & $+1(70)$ & $-1(15)$ & $-1(1)$ & $-1(5)$ & 121.42 & 0.02 & 1.09 & 1482.86 \\
\hline 5 & $-1(2.5)$ & $-1(25)$ & $+1(25)$ & $-1(1)$ & $+1(15)$ & 45.42 & 1.00 & 0.76 & 137.85 \\
\hline 6 & $+1(9.5)$ & $-1(25)$ & $+1(25)$ & $-1(1)$ & $-1(5)$ & 78.47 & 0.19 & 0.88 & 459.77 \\
\hline 7 & $-1(2.5)$ & $+1(70)$ & $+1(25)$ & $-1(1)$ & $-1(5)$ & 1.39 & 0.89 & 0.67 & 250.06 \\
\hline 8 & $+1(9.5)$ & $+1(70)$ & $+1(25)$ & $-1(1)$ & $+1(15)$ & 75.95 & 1.14 & 0.85 & 114.55 \\
\hline 9 & $-1(2.5)$ & $-1(25)$ & $-1(15)$ & $+1(4)$ & $-1(5)$ & 158.33 & 0.20 & 0.87 & 1448.54 \\
\hline 10 & $+1(9.5)$ & $-1(25)$ & $-1(15)$ & $+1(4)$ & $+1(15)$ & 81.53 & 0.19 & 0.87 & 613.97 \\
\hline 11 & $-1(2.5)$ & $+1(70)$ & $-1(15)$ & $+1(4)$ & $+1(15)$ & 72.86 & 1.04 & 0.68 & 114.49 \\
\hline 12 & $+1(9.5)$ & $+1(70)$ & $-1(15)$ & $+1(4)$ & $-1(5)$ & 120.89 & 0.11 & 0.86 & 1324.69 \\
\hline 13 & $-1(2.5)$ & $-1(25)$ & $+1(25)$ & $+1(4)$ & $+1(15)$ & 85.34 & 0.23 & 0.88 & 345.54 \\
\hline 14 & $+1(9.5)$ & $-1(25)$ & $+1(25)$ & $+1(4)$ & $-1(5)$ & 94.84 & 0.19 & 0.86 & 811.95 \\
\hline 15 & $-1(2.5)$ & $+1(70)$ & $+1(25)$ & $+1(4)$ & $-1(5)$ & 6.95 & 1.66 & 0.74 & 1619.15 \\
\hline 16 & $+1(9.5)$ & $+1(70)$ & $+1(25)$ & $+1(4)$ & $+1(15)$ & 60.45 & 0.26 & 0.89 & 388.70 \\
\hline 17 & $0(6)$ & $0(47.5)$ & $0(20)$ & $0(2.5)$ & $0(10)$ & 104.79 & 0.31 & 0.89 & 553.85 \\
\hline 18 & $0(6)$ & $0(47.5)$ & $0(20)$ & $0(2.5)$ & $0(10)$ & 107.42 & 0.30 & 0.91 & 469.64 \\
\hline 19 & $0(6)$ & $0(47.5)$ & $0(20)$ & $0(2.5)$ & $0(10)$ & 105.19 & 0.29 & 0.86 & 509.13 \\
\hline 20 & $0(6)$ & $0(47.5)$ & $0(20)$ & $0(2.5)$ & $0(10)$ & 108.01 & 0.33 & 0.87 & 437.76 \\
\hline
\end{tabular}

The column values $-1,0 \mathrm{e}+1$ are minimum, central and maximum points, respectively.

\subsection{Turbidity of sugarcane juice}

The SCJ's turbidity was measured to determine the amount of cloudiness, and it would be expressed as Nephelometric Turbidity Units (NTU). The turbidity of the samples was obtained by reading on a Tecnopon TB1000 bench-top turbidimeter, properly calibrated against a curve between 0 and 1,000 NTU (Ogando et al., 2019).

\subsection{ICUMSA color of the sugarcane juice}

The ICUMSA color analysis was performed according to the GS2/3-9 method of the ICUMSA Methods (International Commission for Uniform Methods of Sugar Analysis, 2011). First, the Brix of each sample was read in triplicate. Then, the calculation was made for the dilution, in triplicate, of the sample to obtain a 
Brix of 1.25. The samples were filtered through a vacuum filter using cellulose nitrate filter membranes (pore size $0.45 \mu \mathrm{m}$ ) and the $\mathrm{pH}$ was corrected to $7.0 \pm 0.05$. Then, the reading was performed on a spectrophotometer at $420 \mathrm{~nm}$ with a $1 \mathrm{~cm}$ quartz cuvette. The ICUMSA color index was expressed by Equation 1:

Icums a color at $420 \mathrm{~nm}=\left(\frac{A B S \times 1,000}{\operatorname{density} \times \frac{\text { Brix }_{C}}{100}}\right)$

Where: $\mathrm{ABS}=$ absorbance at $420 \mathrm{~nm}$; Brix $_{\mathrm{C}}=$ total soluble solids of diluted sample; and density $=$ calculated by the following Equation 2:

density $=1+\left(\right.$ Brix $_{0} \times\left(\frac{200+\text { Brix }_{C}}{5,400}\right) \times\left(\frac{\text { Brix }_{C}}{\text { Brix }_{0}}\right)$

Where: Brix $_{O}=$ Reading value of soluble solids in the original sample; $B_{1} x_{C}=$ Reading value of soluble solids in the diluted sample with $\mathrm{pH}$ already adjusted.

\subsection{Apparent sucrose content (pol\% juice) of the sugarcane juice}

The analysis of pol\%juice was done through the saccharimetric reading of the clarified samples, using a clarifying mixture based on aluminum, in a polarimeter model ADS 420 (Bellingham + Stanley Ltda.), according to Consecana (Conselho de Produtores de Cana-de-Açúcar, Açúcar e Etanol do Estado de São Paulo, 2015). The conversion of saccharimetric reading with the aluminum-based clarifying mixture $\left(\mathrm{L}_{\mathrm{Al}}\right)$ to the equivalent reading in lead subacetate $\left(\mathrm{L}_{\mathrm{Pb}}\right)$ was done using the following Equations 3 and 4 :

$L_{P b}=\left(\left(1.00621 \times L_{A l}\right)+0.05117\right.$

and the calculation of pol\%juice (S) was done using the equivalent reading in lead subacetate $(\mathrm{LPb})$, or:

$S=L_{P b} \times\left(0.2605-\left(0.0009882 \times\right.\right.$ Brix $\left._{0}\right)$

\subsection{Reducing sugars by 3,5-dinitrosalicylic acid (3,5-DNS)}

According to Miller (1959), $1 \mathrm{~mL}$ of the sample and $1 \mathrm{~mL}$ of 3,5-DNS were pipetted in a test tube, which was placed in a water bath at $100{ }^{\circ} \mathrm{C}$ for $5 \mathrm{~min}$. Then, a second dilution of the sample occurred until the solution was $12.5 \mathrm{~mL}$. Finally, the absorbance at $540 \mathrm{~nm}$ was read on a spectrophotometer (UV-Vis Mini1240, Shimadzu Co.). The absorbance values were associated with the curve equation made previously with standard glucose solutions (between 1 and $5 \mathrm{~g} \mathrm{~L}^{-1}$ ).

\subsection{Quantification of residual aluminum by voltammetry}

Aluminum quantification in treated SCJ was by differential pulse voltammetry technique (Metrohm, 2019). In this analysis were evaluated only samples from Essays 5 which had a great performance in turbidity reduction. The methodology used the complexation of ion $\mathrm{Al}^{3+}$ with calcon (Eriochrome blue-black B metal indicator) in buffered medium at $\mathrm{pH} 4.5$. Minor changes in $\mathrm{pH}$ can shift the aluminum peak in $0.02 \mathrm{~V}$. The formed complex was easily electrochemistry reduced at $60{ }^{\circ} \mathrm{C}$, for that it was used vase with jacket, thermostated bath and peristaltic bomb to circulation.

Initially, samples were treated in digester UV (909 UV Digester, Metrohm). After that, it was put in quartz tube with $5 \mathrm{~mL}$ of ultrapure water and $0.1 \mathrm{~mL}$ of hydrogen peroxide $(30 \%, \mathrm{v} / \mathrm{v})$. After $60 \mathrm{~min}$ at $90{ }^{\circ} \mathrm{C}$, it was added more $1 \mathrm{~mL}$ of hydrogen peroxide $(30 \%, \mathrm{v} / \mathrm{v})$ to the samples, which was digested for another 60 min at $90{ }^{\circ} \mathrm{C}$. Samples were diluted before voltammetry analysis. The digestion step was necessary because preliminary analysis with sugarcane juice did not present peaks after addition of standard of $\mathrm{Al}(\mathrm{III})$, 
indicating that compounds (probably sugars) formed complex with the ions. The concentration of $\mathrm{Al}^{3+}$ was determined according to:

$c\left(A l^{3+}\right)=c_{\text {diluted }}\left(A l^{3+}\right) \times \frac{V_{\text {diluted }}}{V_{\text {sample }}}$

Where $\mathrm{c}\left(\mathrm{Al}^{3+}\right)$ represent the concentration of aluminum in sample without dilution $\left(\mathrm{mg} \mathrm{L}^{-1}\right), \mathrm{c}_{\text {diluted }}\left(\mathrm{Al}^{3+}\right)$ is the concentration of aluminum founded after the analysis $\left(\mathrm{mg} \mathrm{L}^{-1}\right) ; \mathrm{V}_{\text {diluted }}$ is the flask volume used to dilute samples after digestion $(\mathrm{mL})$ and $\mathrm{V}_{\text {diluted }}$ is the aliquot of samples used in digestion $(\mathrm{mL})$.

Reliability tests of aluminum analysis were made with two analysis of recuperation of standard added per samples. At the end, the results of $\mathrm{Al}^{3+}$ recovery in SCJ analysis were inside the normal (between 90 and $110 \%$ ). In addition to that, the external calibration curve after nine $0.05 \mathrm{~mL}$ addition of $\mathrm{Al}(\mathrm{III})$ standard solution $\left(1 \mathrm{mg} \mathrm{L}^{-1}\right)$ had determination coefficient $\left(\mathrm{R}^{2}\right)$ of 0.9922 (results not shown - preliminary studies). This indicated that additions were inside the linear range of methodology.

Analyses were carried out in triplicate and the collected data were evaluated according to mean followed by standard deviation, through statistical package $\mathrm{R}$. The data were also submitted to ANOVA through $\mathrm{F}$ test and the means was compared by Tukey's test at $1 \%$ probability level.

\section{Results and discussions}

Most of the factor was significant and reduced ICUMSA color. The single factors, distance and voltage and the double interaction voltage*Brix stood out in the Pareto chart as the most significant parameter. However, the double interaction $\mathrm{pH}^{*}$ distance and triple interaction distance*temperature*Brix did not influence the ICUMSA color (Figure 2). The lower ICUMSA color, clearer was the SCJ or whiter would be the sugar.
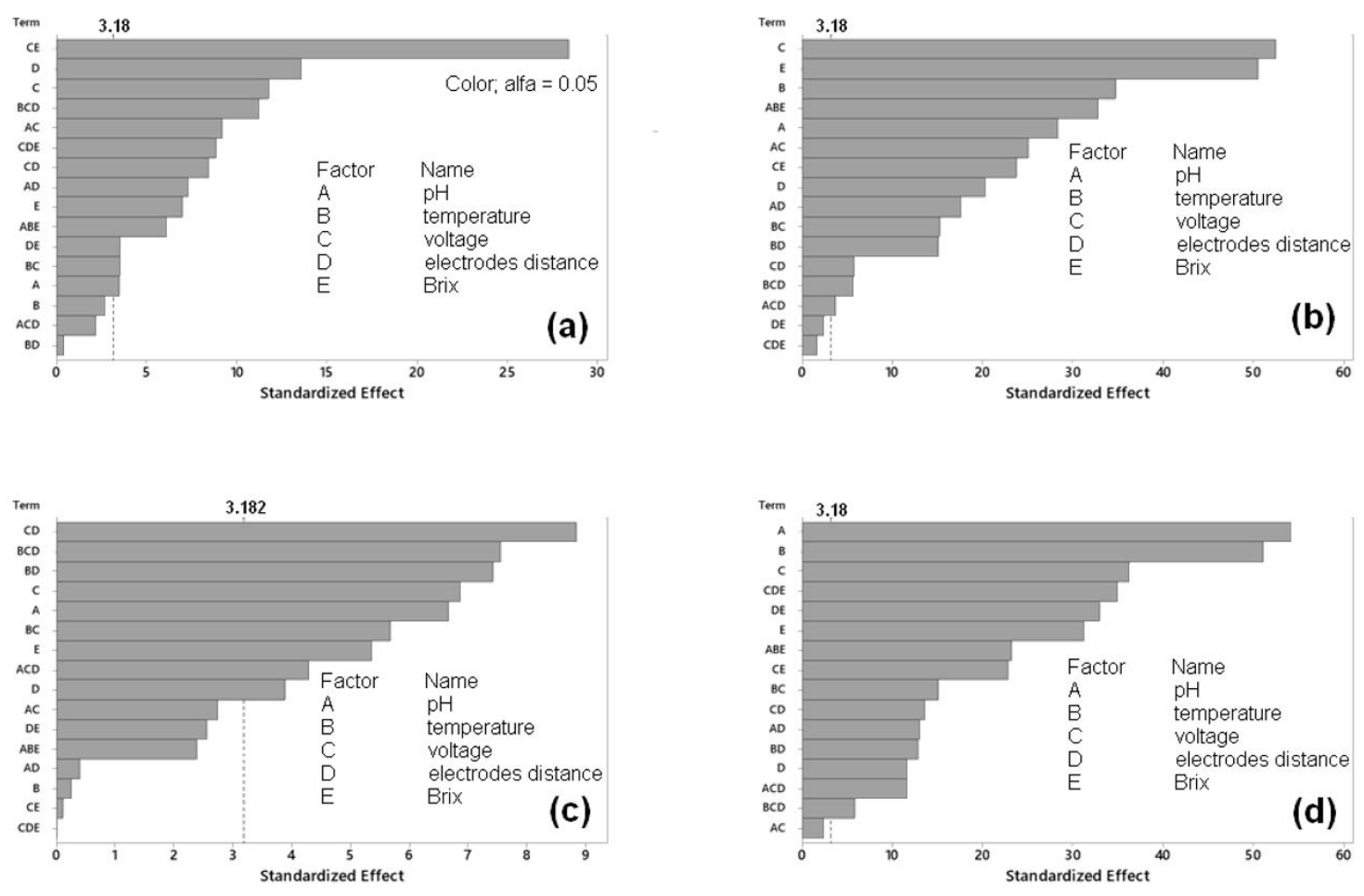

Figure 2. Pareto ( $5 \%$ of significance) of influences from $\mathrm{pH}$, temperature (Temp.), voltage (Volt.), distance between electrodes (Dist.), percentage of total soluble solids (Brix) and their respective interactions in the analysis of ICUMSA color (a), turbidity (b), pol\%juice (c) and RS (d) from the samples treated by electrocoagulation. The bars that extend beyond the horizontal line indicated significance. 
Variations in factors voltage and distance led to greater amplitudes of ICUMSA color (Figure 3). Higher voltage applied led to lower ICUMSA color, whereas distance between electrodes shorter led to greater ICUMSA color reduction.
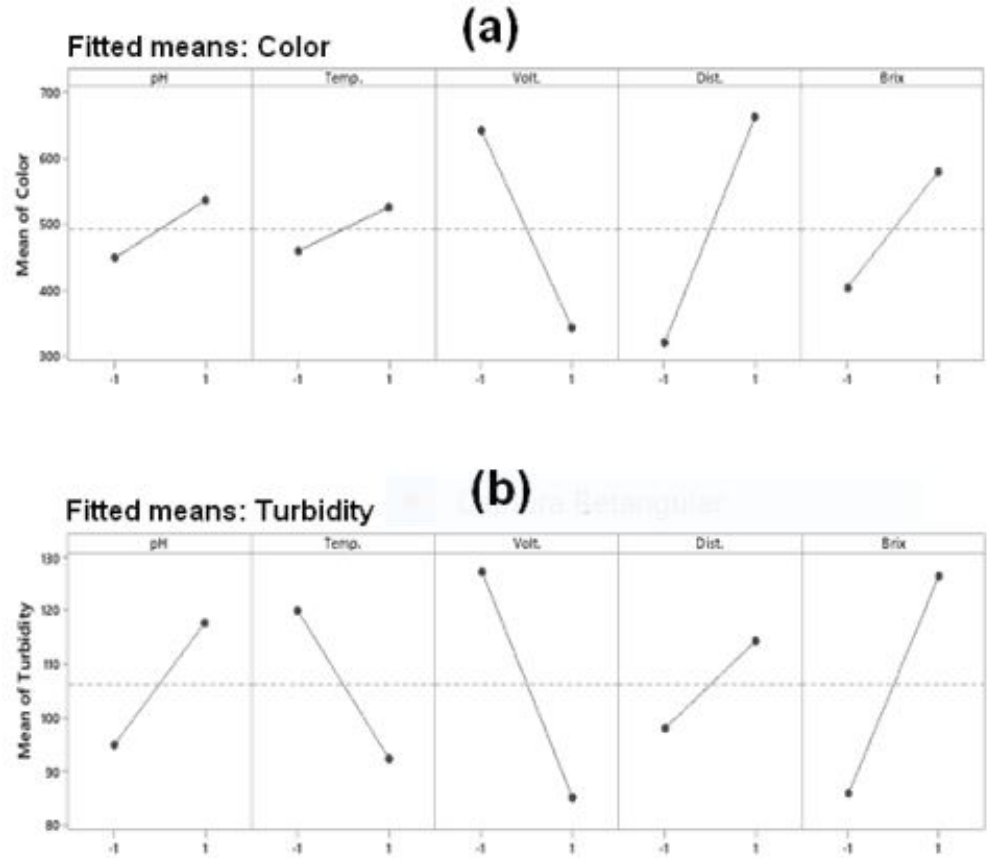

(c)

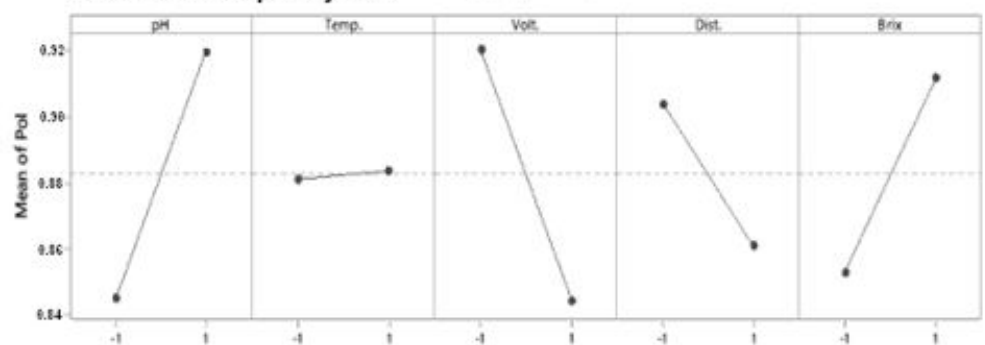

(d)

Fitted means: Reducing sugars

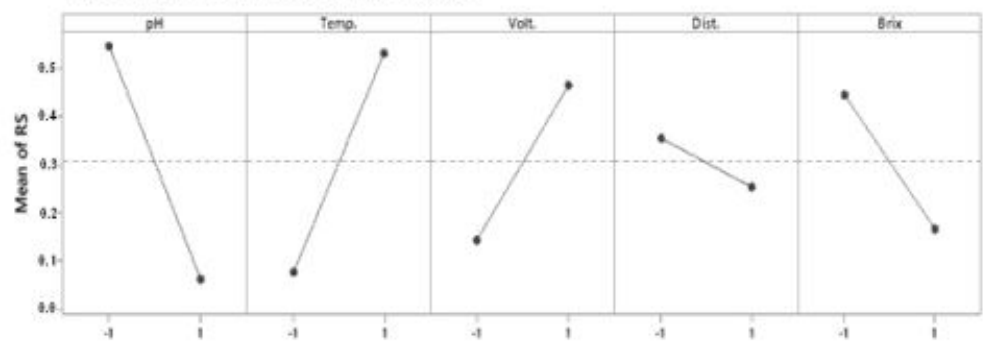

Figure 3. Medium effect of factors none combined for of ICUMSA color (a), turbidity (b), pol\%juice (c) and RS (d) from samples of SCJ treated by electrocoagulation. Temp. means temperature, Volt. means voltage and Dist. means distance between electrodes. The axis $\mathrm{X}$ values, -1 and 1 indicated the maximum and minimum conditions tested, whereas $\mathrm{Y}$ axis was the mean values from ICUMSA color.

The contour plots (Figure 4) between voltage and other factors showed that lowers values of ICUMSA color was obtained when applied higher voltage, independent of the combinations. The 
lowest values of ICUMSA color were obtained by combining higher voltage with lower distance between electrodes. Then, voltage was a significant factor in reduction of SCJ ICUMSA color treated by electrocoagulation with aluminum electrodes. Higher voltage generated more flocs (Al polymer and organic matter) and consequently increased the removal efficiency of organic material, including phenolic compounds (Tchamango et al., 2010; Stahl et al., 2011), which was related to the sugarcane juice color (Nguyen \& Doherty, 2011). Hu et al., (2016) reported that aluminum hydrolysis reactions during electrocoagulation process, active coagulant species were generated in situ by anodic dissolution of sacrificial $\mathrm{Al}$ electrode. $\mathrm{Al}_{13}$ species could be generated and they were positively correlated with the removal of turbidity.
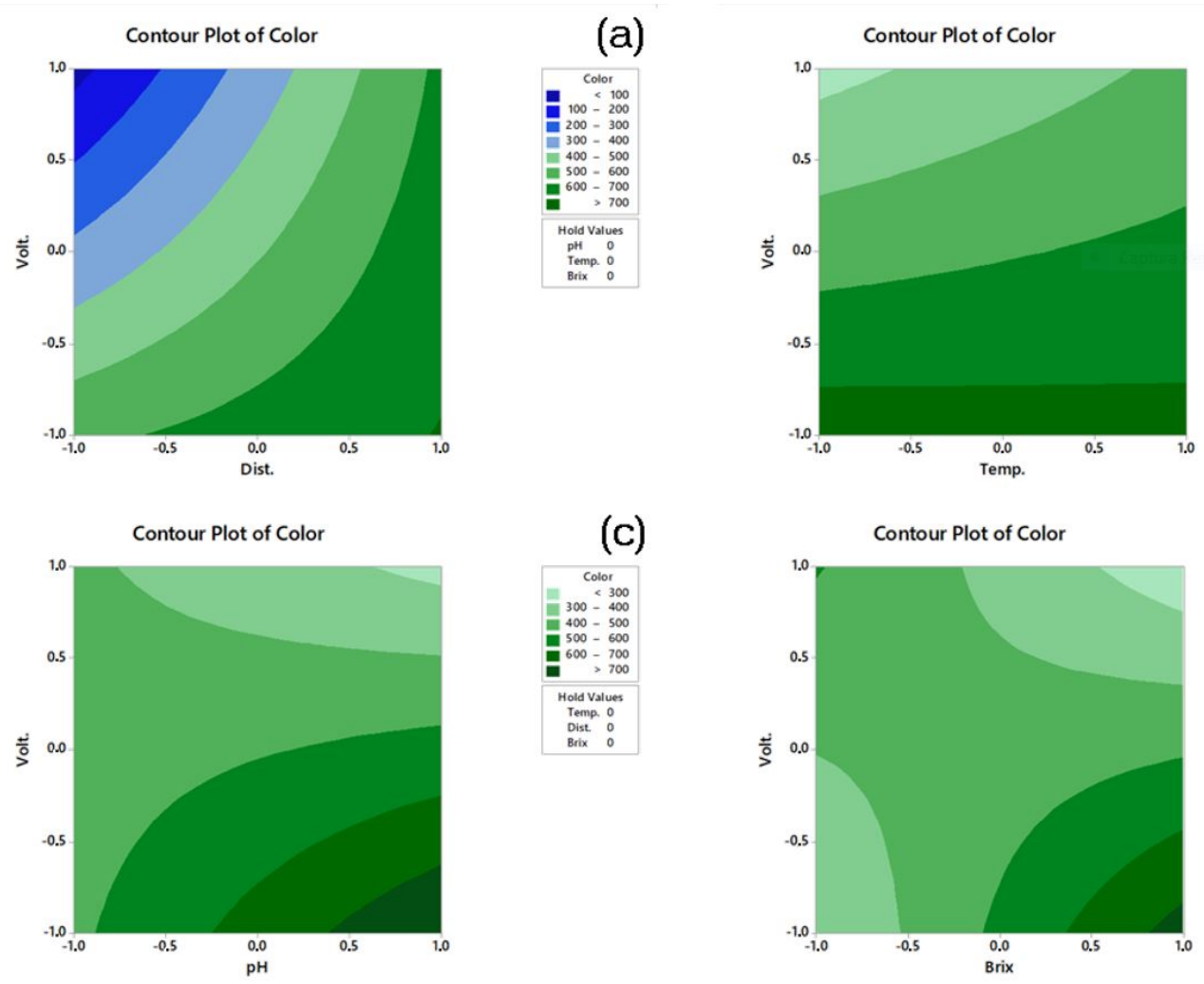

Figure 4. Contour plot for ICUMSA color in SCJ treated by electrocoagulation. The interactions involving voltage (Volt.) and (a) distance between electrodes (Dist.); (b) temperature (Temp.), (c) pH and (d) Brix. The values of X and $\mathrm{Y}$ axis, -1 and 1, represented factors maximum and minimum point, respectively.

When combined lower voltage with large distance between electrodes, ICUMSA color was seven times ( $86 \%$ of reduction) higher than after combination between higher voltage and shorter distance between electrodes. This variation was elevated when compared with other alternative process. According to Sartori et al. (2017a), they found a reduction of $16 \%$ in ICUMSA color of SCJ after applying 50,000 ppm of hydroxide peroxide. Meanwhile, Mbanjwa et al. (2011) showed a reduction between 11 and 15\% comparing with a control after applying $300 \mathrm{ppm}$ of hydrogen peroxide in sugar solutions during refining process. In this sense, the use of hydrogen peroxide was efficient in the removal of sugarcane juice impurities; however, this process required large amounts of chemical inputs. This fact has promoted in our research group the search for green technologies and with lower operation costs. Electrocoagulation has proven to be efficient and is a simple technique to be deployed and operated in the sugar production mills. 
In the regression model analysis for ICUMSA color, the regression equation (Equation 6) had an adjusted and predicted determination coefficient $\left(\mathrm{R}^{2}\right)$ of 0.9982 and 0.9887 , respectively. The high adjusted $\mathrm{R}^{2}$ value indicated that regression equation of ICUMSA color explained almost perfectly the impact of parameters in outputs, whereas predicted $\mathrm{R}^{2}$ near to 1 indicated that regression model was capable to predict answers in new observations within the intervals worked. In this case, according to Ogando et al. (2019), the equation was predictive.

Comparing the experimental values with predict values by equation, it was noted that median of results showed higher reproducibility. Although, some outliers were noted and for those cases the proposed model could not predict.

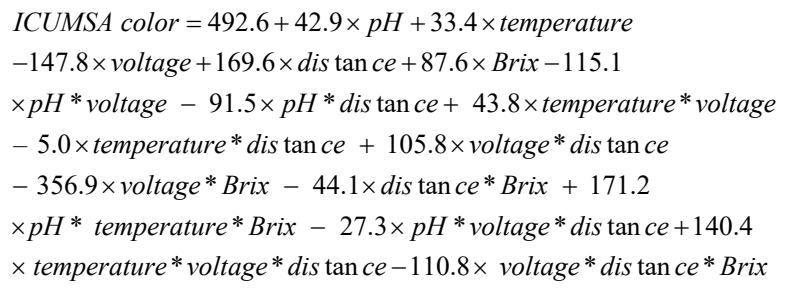

Wherein, ${ }^{*}$ indicates the interactions.

Voltage, Brix and temperature according to analysis of variance and Pareto were the factors that most influenced the turbidity in SCJ treated by electrocoagulation. Meanwhile, the only factors not significance were the double combination distance*Brix and triple combination voltage*distance*Brix (Figure 2b).

Turbidity decrease was expressed by removing impurities (flocs) in SCJ suspension. The combination $\mathrm{pH}^{*}$ voltage also stood out. Indeed, $\mathrm{pH}$ had important role in the mechanism action of electrocoagulation, once the species of aluminum hydroxide formed depends on initial $\mathrm{pH}$. The released $\mathrm{Al}^{3+}$ during electrocoagulation participates in various hydrolysis, leading to the formation of diverse monomeric species of Al. According to Sartori et al. (2015), the reaction sequence that happens was described by Equations 7, 8 and 9:

$$
\begin{aligned}
& \mathrm{Al} \rightarrow \mathrm{Al}^{3+}+3 e^{-} \\
& 2 \mathrm{H}_{2} \mathrm{O}+2 e^{-} \rightarrow \mathrm{H}_{2}(\mathrm{~g})^{+}+2 \mathrm{OH}^{-} \\
& \mathrm{Al}^{3+}{ }_{(\mathrm{aq})}+3 \mathrm{H}_{2} \mathrm{O} \rightarrow \mathrm{Al}(\mathrm{OH})_{3}+3 \mathrm{H}^{+}{ }_{(a q)}
\end{aligned}
$$

Depending of $\mathrm{pH}$ solution, from $\mathrm{Al}(\mathrm{OH})_{3}$ could promote the formation of ionic species different, for example, $\mathrm{Al}(\mathrm{OH})_{4}{ }^{-}$and $\mathrm{Al}_{2}(\mathrm{OH})_{2}{ }^{4+}$ or polymeric species as $\mathrm{A}_{13}(\mathrm{OH})_{34^{5+}}$. Finally, at the end of flocculation, a solid species $\mathrm{Al}(\mathrm{OH})_{3}$ was formed and it could sediment quickly with colloidal impurities, once they had high density and molecular weight (Hu et al., 2016; Tak et al., 2015).

As well as for ICUMSA color, the increased of voltage meant expressive amplitude between turbidity and higher voltage caused lower turbidity. Temperature had a similar effect, however with less amplitude, whereas Brix, $\mathrm{pH}$ and distance had inverse behavior (Figure 3b).

The voltage behavior combined with other factors indicated lower values of turbidity when it was applied higher voltage. The combination with high temperature $\left(70^{\circ} \mathrm{C}\right)$ and low $\mathrm{pH}(=2.5)$ achieved the lowest turbidity (Figure 5). At high $\mathrm{pH}$, occurred the accumulation of $\mathrm{OH}^{-}$in the solution, compromising the release of hydrogen by cathode (Tak et al., 2015). It was concluded that the electrocoagulation treatment was capable to reduce suspended solids (organic matter as non-sugars) in $\mathrm{SCJ}$ and then reduced turbidity. 

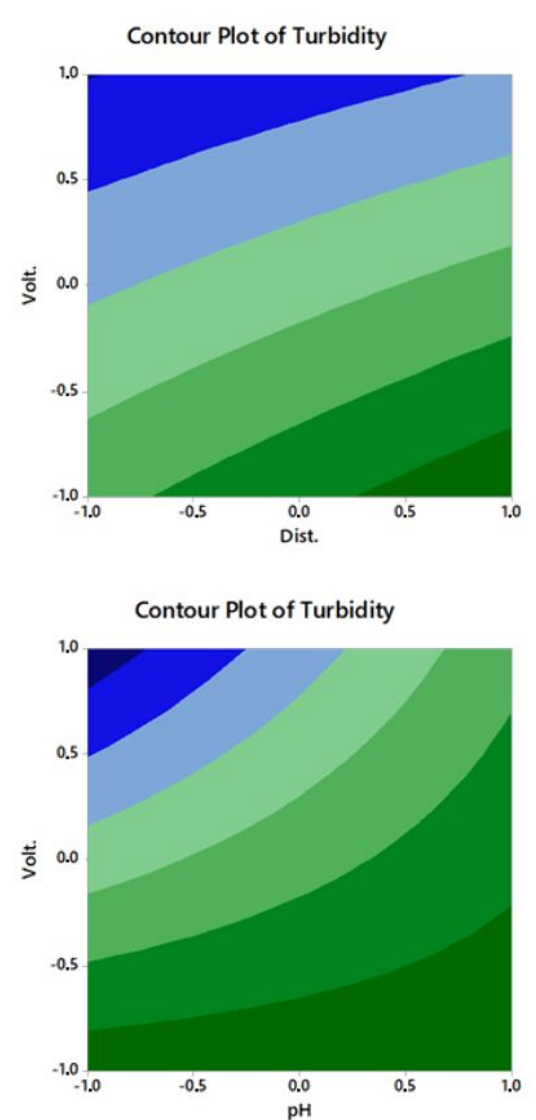

(a)

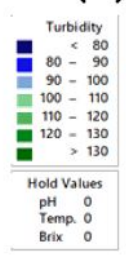

(c)

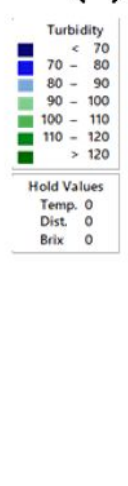

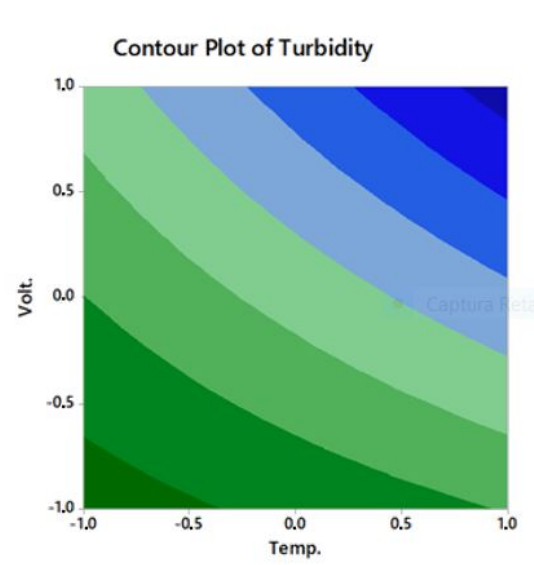

(b)

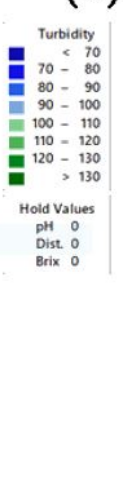

(d)

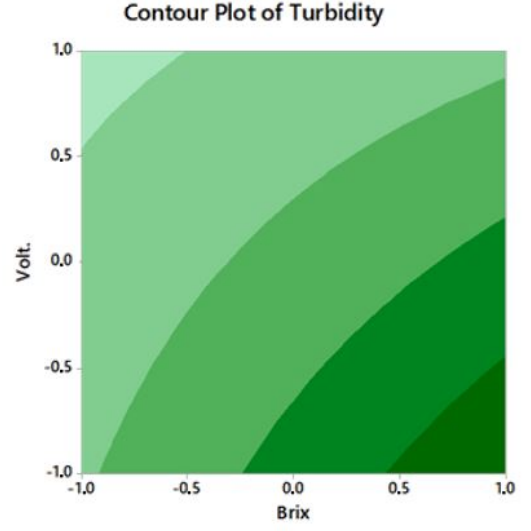

Figure 5. Contour plot for turbidity in SCJ treated by electrocoagulation. The interactions involving voltage (Volt.) and (a) distance between electrodes (Dist.); (b) temperature (Temp.), (c) pH and (d) Brix. The values of X and Y axis, -1 and 1 , represented factors maximum and minimum point, respectively.

In the regression analysis of turbidity (Equation 10), the coefficient of determination value $\left(\mathrm{R}^{2}\right)$ presented closer to 1 than for ICUMSA color. The adjusted $R^{2}$ was 0.9997 , whereas predicted $R^{2}$ was 0.9982 . Identically to occurred for ICUMSA color model, turbidity model presented a low error when considered the median of experimental results, however the error was higher in outlier cases.

Turbidity $=106.4+11.3 \times p H+13.9 \times$ temperature $-21.0 \times$ voltage

$+8.1 \times$ distance $+20.2 \times$ Brix $-10.0 \times p H^{*}$ voltage $-7.0 \times p H^{*}$ distance

$+6.1 \times$ temperature $*$ voltage $-6.0 \times$ temperature $*$ distance

$+2.3 \times$ voltage $*$ distance $-9.5 \times$ voltage $*$ Brix $-0.9 \times$ distance $*$ Brix

$+29.3 \times p H^{*}$ temperature $*$ Brix $-1.4 \times p H^{*}$ voltage $*$ distance

$+2.3 \times$ temperature $*$ voltage $*$ distance $-0.6 \times$ voltage $*$ distance $*$ Brix

Wherein, * indicates the interactions.

In variance analysis of the process impact in apparent sucrose (pol\%juice), double combinations voltage*distance and temperature*distance, plus the triple combination temperature*voltage*distance were the only factor with significance (Figure 2c).

It was noticed that voltage had a negative impact on pol\%juice, in other words, higher voltage led to apparent sucrose loss. In the turbidity and color ICUMSA analysis, lower distance between electrodes indicated a greater effect in both outputs. The reverse behavior of pol\%juice was important once it would allow work in best conditions to reduce impurities, without sucrose reduction (Figure 3c). The non-effect of temperature is an important observation, once allows a flexibilization of these parameters in the moment of 
optimization. And it is an important control parameter at sugarcane industry, once higher temperature means higher steam costs and it is also related to sucrose degradation (Eggleston et al., 2014).
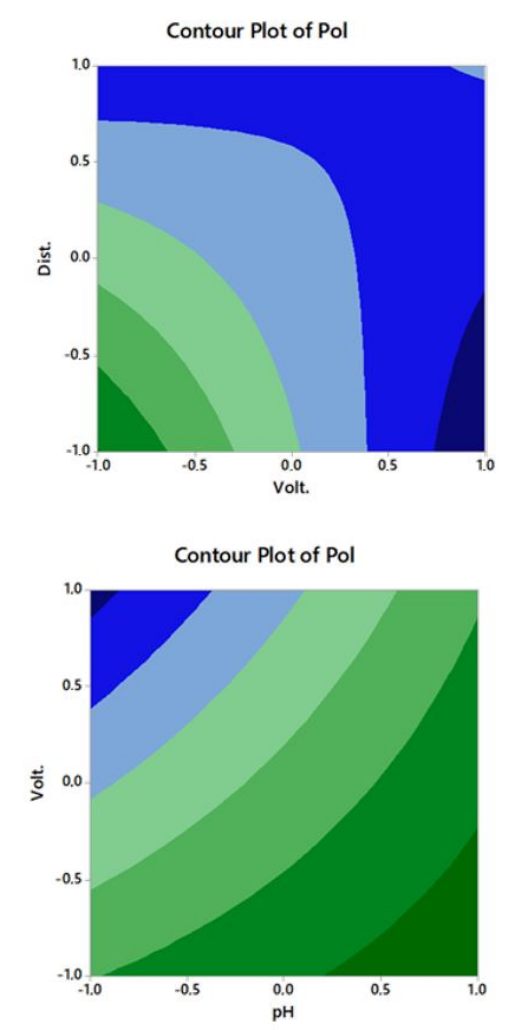

(a)

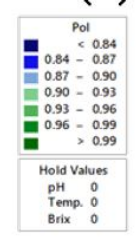

(c)

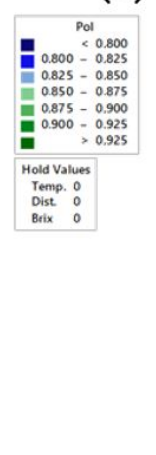

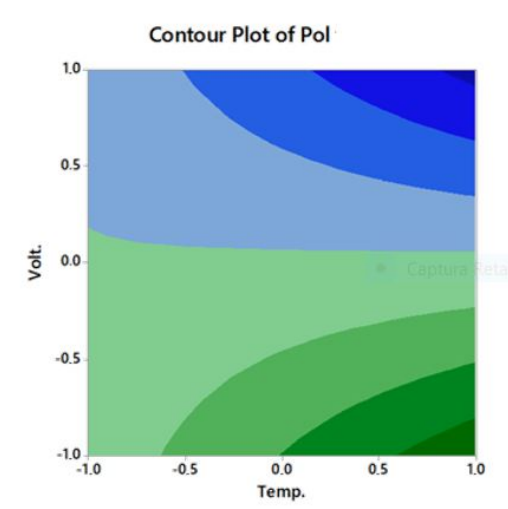

(b)

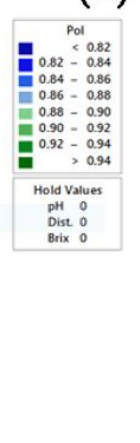

(d)

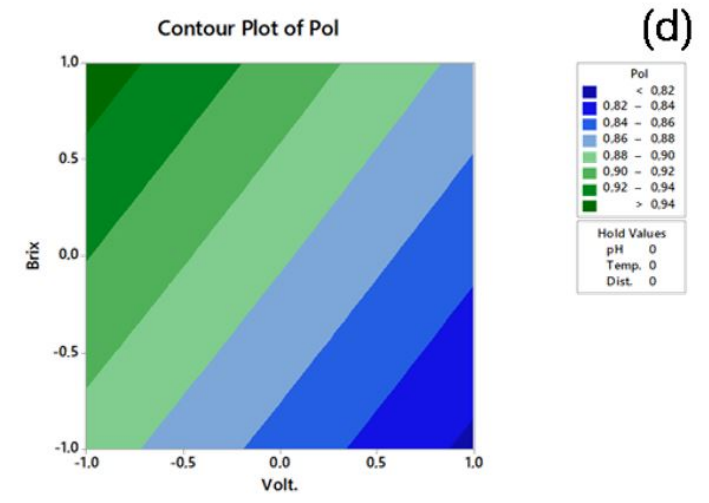

Figure 6. Contour plot for pol\%juice in SCJ treated by electrocoagulation. The interactions involving voltage (Volt.) and (a) distance between electrodes (Dist.); (b) temperature (Temp.), (c) pH and (d) Brix. The values of X and Y axis, -1 and 1 , represented factors maximum and minimum point, respectively.

The interpretation of higher values of pol\%juice at basic $\mathrm{pH}$ (Figure 6) must be interpreted as the more negative effect of acid conditions, once according to Eggleston \& Vercellotti (2000), there were studies showing that sucrose is degraded in solutions with $\mathrm{pH}$ outside the range of 5.5-7.0. Lower concentrations of pol\%juice was obtained with higher voltage, once in this situations there were greater release of $\mathrm{Al}^{3+}$ and, consequently greater removal of organic compounds, including sucrose. Bazrafshan et al. (2013) showed similar results. Lower concentrations of apparent sucrose were obtained with shorter distance between electrodes, lower $\mathrm{pH}$ and Brix, and higher temperature. The difference between the highest range and lowest range was 13\% (0.925 and 0.800) (Figure 3). Eggleston et al. (2014) tested two coagulants in clarification step and found sucrose loss of $0.4 \%$ after using calcium saccharate and $3.6 \%$ with lime milk at the end of treatment. In the same work, the authors calculated a daily financial loss and showed that lime milk generated a cost of US\$22/day higher than calcium saccharate. Then, even small sucrose loss resulted in great financial losses.

The coefficient of determination $\left(\mathrm{R}^{2}\right)$ in the pol\%juice analysis was near 1 (Equation 11). The adjusted $\mathrm{R}^{2}$ was 0.9925 and predictive $\mathrm{R}^{2} 0.9524$ and both had significance. Over again, it was not possible to preview outliers from experimentation.

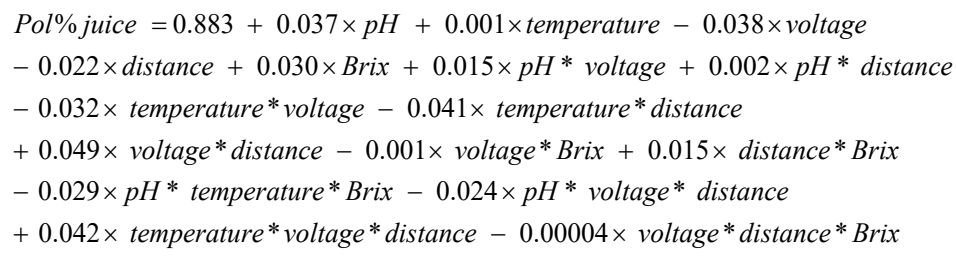


Wherein, * indicates the interactions.

Sucrose degradation initially led to formation of reducing sugars (glucose and fructose) (Martins et al., 2001). In the analysis of variance only double combination $\mathrm{pH}^{*}$ voltage had significance (Figure 2d).

It was not possible to establish a perfect parallel between RS and pol\%juice analysis because they had different principles, subjected to different influencers. However, some tendencies were noticed. The factor $\mathrm{pH}$, temperature and voltage had acted inversely to the noticed in pol\%juice, in other words, the higher temperature and voltage in acid conditions led to higher concentrations of reducing sugars. Then, there was a tendency to sucrose inversion to glucose and fructose when applied electrocoagulation (Figure 3d).

Evaluating the influence of combination between voltage and other factors, it was conclusive that voltage had strong correlation with reducing sugar concentration. Increasing voltage resulted in increase of reducing sugars. Higher values of reducing sugar could be founded combining with acid pH (Figure 7).
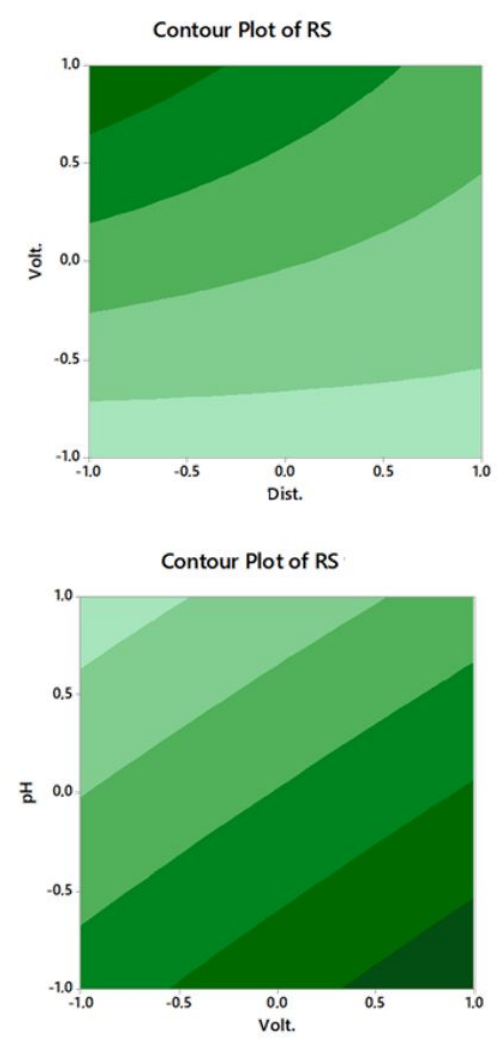

(a)

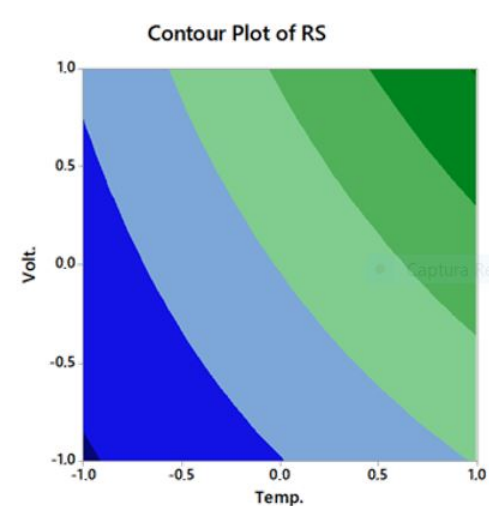

(c)

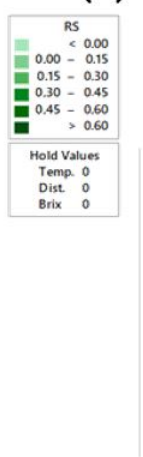

(b)
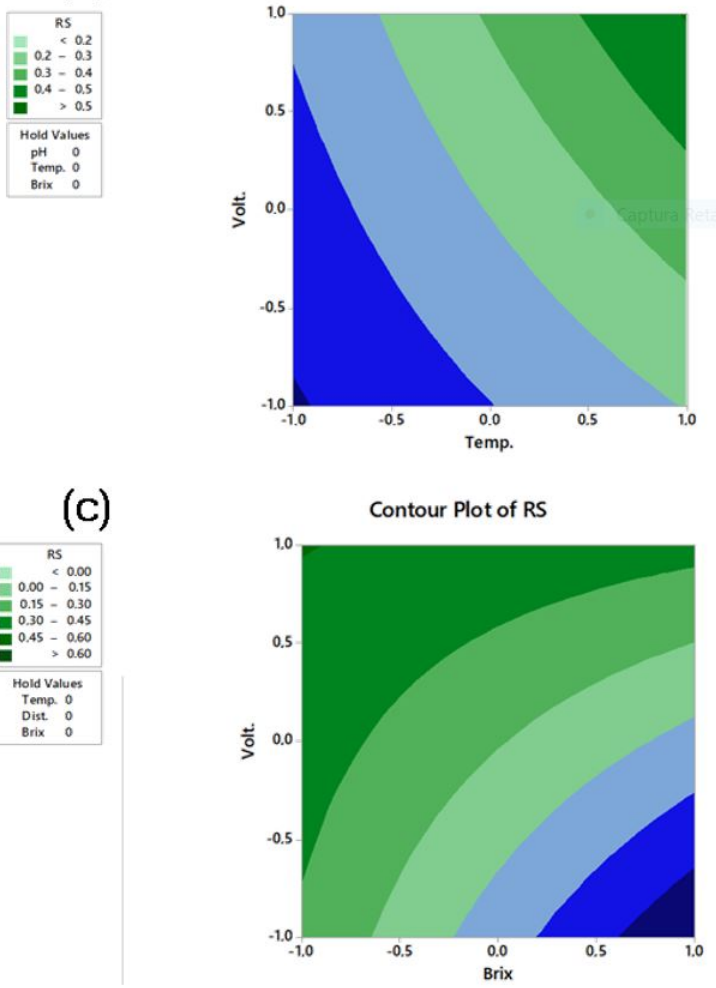

(d)

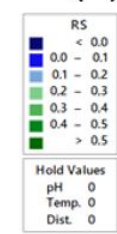

Figure 7. Contour plot for reducing sugars (glucose+fructose) in SCJ treated by electrocoagulation. The interactions involving voltage (Volt.) and (a) distance between electrodes (Dist.); (b) temperature (Temp.), (c) pH and (d) Brix.

The values of $\mathrm{X}$ and $\mathrm{Y}$ axis, -1 and 1, represented factors maximum and minimum point, respectively

The analysis of regression of reducing sugar indicated a determination coefficient $\left(\mathrm{R}^{2}\right)$ closer to 1 than the other. The adjusted and predictive $\mathrm{R}^{2}$ were 0.9998 and 0.9984 , respectively (Equation 12). Just like for the other models, outliers were not suitable.

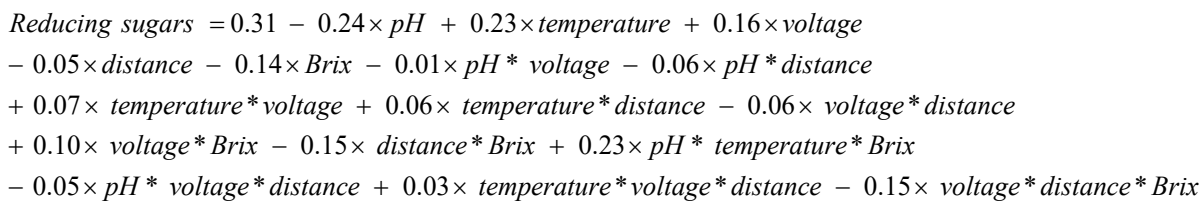

Wherein, * indicates the interactions. 
After analyzing the parameters, it was done an analysis of residual aluminum in the three phases after electrocoagulation. Without any treatment, SCJ presented $10.9 \mathrm{mg} \mathrm{L}^{-1}$ of $\mathrm{Al}^{3+}$ (Table 3). This value was inside the range value normally found between 7 and $15 \mathrm{mg} \mathrm{L}^{-1}$ (Souza et al., 2016).

Table 3. Aluminum concentration in SCJ without treatment and after electrocoagulation treatment (Essay 5 and Essay 8) of factorial fractional.

\begin{tabular}{cccc}
\hline & \multicolumn{2}{c}{ Aluminum $\left(\mathbf{m g ~ L}^{-\mathbf{1}}\right)$} & \\
\hline Samples & Mean & Standard deviation & Coefficient of variation \\
\hline SCJ without treatment & 10.9 & 0.5 & $5 \%$ \\
\hline Essay 5 - Clarified & 107.0 & 2.6 & $2 \%$ \\
\hline Essay 5 - Floated & 1619.7 & 17.0 & $1 \%$ \\
\hline Essay 5 - Precipitate & 383.0 & 6.6 & $2 \%$ \\
\hline Essay 8 - Floated & 2986.7 & 166.5 & $6 \%$ \\
\hline Essay 8 - Clarified & 1497.0 & 86.9 & $6 \%$ \\
\hline
\end{tabular}

The Essay 5 presented very high concentration of aluminum in the three phases (clarified, floated and precipitated: $2,109.7 \mathrm{mg} \mathrm{L}^{-1}$ ). However, the most part of aluminum was concentrated in foam (76.8\%) and in the mud $(18.1 \%)$, whereas it was found only $5.1 \%$ in the clarified juice. It was believed that the mechanism is similar presented by Jiang et al. (2002). The electrodes could release Al(III) ions that was not dissolved in the solution, the flocs formed with impurities were floated after being captured by hydrogen gas bubbles generated in the cathode surface.

This distribution of aluminum was important once there are many works presenting risks to the health related to aluminum in food (Aguilar et al., 2008). Although, the aluminum concentration in the SJC clarified (107.0 $\mathrm{mg} \mathrm{L}^{-1}$ ) was within the ranges raised by Stahl et al. (2011), they evaluated 1,431 samples from European Community (breads, pastas, teas, chocolates, candies, wines, among others) and concluded that aluminum concentration varied between 0.4 and $737 \mathrm{mg} \mathrm{kg}^{-1}$.

Then, the concentration of aluminum in SJC clarified did not limit the technique. Water treatment plants use aluminum sulfate as coagulant and even though the limit of aluminum in drink water is very low, i.e., around 100 and $200 \mu \mathrm{g} \mathrm{L}^{-1}$ (Zhang et al., 2016). The low presence of aluminum after the treatment happened once the quantity applied was optimized (Sillanpää et al., 2018). The same can be done with electrocoagulation, once the process duration can be optimized according to aluminum deposited. Furthermore, electrocoagulation can be coupled with decantation. Decantation applied normally in sugarcane industry could decrease the concentration of aluminum from $15.0 \mathrm{mg} \mathrm{kg} \mathrm{kg}^{-1}$ to around $1.0 \mathrm{mg} \mathrm{kg} \mathrm{g}^{-1}$ (Takahashi et al., 2016; Asikin et al., 2018).

\section{Conclusion}

The electrocoagulation decreased color and turbidity. The best condition for ICUMSA color and turbidity reduction was associated with higher voltage $(25 \mathrm{~V})$, shorter distance of electrodes and lowest $\mathrm{pH}$. Though, this same condition was related to sucrose degradation and more RS content. It was also possible to conclude that voltammetry was an efficient technique for the determination of $\mathrm{Al}^{3+}$ in sugarcane juice and the concentration of residual aluminum was not a problem regarding the process.

\section{Acknowledgements}

The authors are grateful to The São Paulo Research Foundation (Fundação de Amparo à Pesquisa do Estado de São Paulo (FAPESP)) for F.I.B. Ogando grant (2016/05123-1 and 2018/01452-6) and to The 
Brazilian National Council for Scientific and Technological Development (Conselho Nacional de Desenvolvimento Científico e Tecnológico (CNPq), 402835/2018-2) for the financial support.

\section{References}

Aguilar, F., Autrup, H., Barlow, S., Castle, L., Crebelli, R., Dekant, W., Engel, K. H., Gontard, N., Gott, D., Grilli, S., Gürtler, R., Larsen, J. C., Leclerq, C., Leblanc, J. C., Malcata, F. X., Mennes, W., Milana, M. R., Pratt, I., Rietjens, I., Tobback, P., \& Toldrá, F. (2008). Safety of aluminium from dietary intake: Scientific opinion of the panel on food additives, flavourings, processing aids and food contact materials (AFC). EFSA Journal, 6(7), 1-34.

Akhtar, A., Subbiah, S., Mohanty, K., Sundar, R., Unnikrishnan, R., \& Hareesh, U.S. (2020a). Sugarcane juice clarification by lanthanum phosphate nanofibril coated ceramic ultrafiltration membrane: PPO removal in absence of lime pre-treatment, fouling and cleaning studies. Separation and Purification Technology, 249, 117157. http://dx.doi.org/10.1016/j.seppur.2020.117157

Akhtar, A., Aslam, Z., Asghar, A., Bello, M. M., \& Raman, A. A. A. (2020b). Electrocoagulation of Congo Red dye-containing wastewater: Optimization of operational parameters and process mechanism. Journal of Environmental Chemical Engineering, 8 , 104055. http://dx.doi.org/10.1016/j.jece.2020.104055

Asha, G., \& Kumar, B. (2016). Comparison of aluminum and iron electrodes for COD reduction from coffee processing wastewater by electrocoagulation process. Journal of Scientific Research and Reports, 9(7), 1-10. http://dx.doi.org/10.9734/JSRR/2016/22815

Asikin, Y., Wada, K., Imai, Y., Kawamoto, Y., Mizu, M., Mutsuura, M., \& Takahashi, M. (2018). Compositions, taste characteristics, volatile profiles, and antioxidant activities of sweet sorghum (Sorghum bicolor L.) and sugarcane (Saccharum officinarum L.) syrups. Journal of Food Measurement and Characterization, 12(2), 884-891. http://dx.doi.org/10.1007/s11694-017-9703-2

AzevedoA. C. B.SilvaF. L. H.MedeirosL. L.QueirozA. L. M.SantosS. F. M.GomesJ. P.FiguerôaJ. A.2019Enzymatic polyphenoloxidase inactivation with temperature and ozone in sugarcane variety RB 92579 to produce lower color sugar.Brazilian Journal of Food Technology22e2018043https://doi.org/10.1590/1981-6723.04318

Bazrafshan, E., Moein, H., Kord Mostafapour, F., \& Nakhaie, S. (2013). Application of electrocoagulation process for dairy wastewater treatment. Journal of Chemistry, 2013, 7-10. http://dx.doi.org/10.1155/2013/640139

Campiol, J. L. M., Magri, N. T. C., Sartori, J. A. S., Ogando, F. I. B., \& Aguiar, C. L. (2019). Color reduction of raw sugar syrup using hydrogen peroxide. Brazilian Journal of Food Technology, 22, e2018072. https://doi.org/10.1590/1981-6723.07218.

Colomina, M. T., \& Peris-Sampedro, F. (2017). Aluminum and Alzheimer's disease. In: M. Aschner \& L. Costa (eds), Neurotoxicity of Metals (Advances in Neurobiology, Vol. 18, pp. 183-197). Springer. https://doi.org/10.1007/978-3-319-60189-2_9.

Conselho de Produtores de Cana-de-Açúcar, Açúcar e Etanol do Estado de São Paulo - CONSECANA. (2015). Instruction manual of Council of Sugar Cane, Sugar and Ethanol Producers of the State of São Paulo (6th ed., 81 p.). Piracicaba: CONSECANA.

D'Amore, T., Di-Taranto, A., Berardi, G., Vita, V., Marchesani, G., Chiaravalle, A. E., \& lammarino, M. (2020). Sulfites in meat: Occurrence, activity, toxicity, regulation and detection. A comprehensive review. Comprehensive Reviews in Food Science and Food Safety, 19, 2701-2720. https://doi.org/10.1111/1541-4337.12607.

Eggleston, G., \& Vercellotti, J. R. (2000). Degradation of sucrose, glucose and fructose in concentrated aqueous solutions under constant $\mathrm{pH}$ conditions at elevated temperature. Journal of Carbohydrate Chemistry, 19(9), 1305-1318. http://dx.doi.org/10.1080/07328300008544153

Eggleston, G., Legendre, D., Pontif, K., \& Gober, J. (2014). Improved control of sucrose losses and clarified juice turbidity with lime saccharate in hot lime clarification of sugarcane juice and other comparisons with milk of lime. Journal of Food Processing and Preservation, 38(1), 311-325. http://dx.doi.org/10.1111/j.1745-4549.2012.00779.x

Emamjomeh, M. M., \& Sivakumar, M. (2009). Review of pollutants removed by electrocoagulation and electrocoagulation/flotation processes. Journal of Environmental Management, 90(5), 1663-1679. PMid:19181438. http://dx.doi.org/10.1016/j.jenvman.2008.12.011

Garcia-Segura, S., Eiband, M. M. S. G., de Melo, J. V., \& Martínez-Huitle, C. A. (2017). Electrocoagulation and advanced electrocoagulation processes: A general review about the fundamentals, emerging applications and its association with other technologies. Journal of Electroanalytical Chemistry (Lausanne, Switzerland), 801, $267-299$.

http://dx.doi.org/10.1016/j.jelechem.2017.07.047

Hakizimana, J. N., Gourich, B., Chafi, M., Stiriba, Y., Vial, C., Drogui, P., \& Naja, J. (2017). Electrocoagulation process in water treatment: A review of electrocoagulation modeling approaches. Desalination, 404, 1-21. http://dx.doi.org/10.1016/j.desal.2016.10.011

Han, Z., Qi, F., Li, R., Wang, H., \& Sun, D. (2020). Health impact of odor from on-situ sewage sludge aerobic composting throughout different seasons and during anaerobic digestion with hydrolysis pretreatment. Chemosphere, 249, 126077. http://dx.doi.org/10.1016/j.chemosphere.2020.126077.

Hashim, K. S., Hussein, A. H., Zubaidi, S. L., Kot, P., Kraidi, L., Alkhaddar, R., Shaw, A., \& Alwash, R. (2019). Effect of initial pH value on the removal of reactive black dye from water by electrocoagulation (EC) method. Journal of Physics Conference Series, 1294(7), 072017. https://doi.org/10.1088/1742-6596/1294/7/072017.

Hu, C., Wang, S., Sun, J., Liu, H., \& Qu, J. (2016). An effective method for improving electrocoagulation process: optimization of Al13 polymer formation. Colloids and Surfaces. A, Physicochemical and Engineering Aspects, 489, 234-240.

http://dx.doi.org/10.1016/j.colsurfa.2015.10.063

International Commission for Uniform Methods of Sugar Analysis - ICUMSA. (2011). International Comission for Uniform Methods of Sugar Analysis (GS1/3-7). Netherlands: ICUMSA. 
Jiang, J. Q., Graham, N., André, C., Kelsall, G. H., \& Brandon, N. (2002). Laboratory study of electro-coagulation-flotation for water treatment. Water Research, 36(16), 4064-4078. PMid:12405415. http://dx.doi.org/10.1016/S0043-1354(02)00118-5

Kobya, M., Demirbas, E., Ozyonar, F., Sirtbas, G., \& Gengec, E. (2017). Treatments of alkaline non-cyanide, alkaline cyanide and acidic zinc electroplating wastewaters by electrocoagulation. Process Safety and Environmental Protection, 105, 373-385. http://dx.doi.org/10.1016/j.psep.2016.11.020

Kushwaha, J. P., Srivastava, V. C., \& Mall, I. D. (2010). Organics removal from dairy wastewater by electrochemical treatment and residue disposal. Separation and Purification Technology, 76(2), 198-205. http://dx.doi.org/10.1016/j.seppur.2010.10.008

Kyzas, G. Z., \& Matis, K. A. (2016). Electroflotation process: a review. Journal of Molecular Liquids, 220, 657-664. http://dx.doi.org/10.1016/j.molliq.2016.04.128

Li, W., Ling, G., Lei, F., Li, N., Peng, W., Li, K., Lu, H., Hang, F., \& Zhang, Y. (2018). Ceramic membrane fouling and cleaning during ultrafiltration of limed sugarcane juice. Separation and Purification Technology, 190, 9-24.

Liaquat, L., Sadir, S., Batool, Z., Tabassum, S., Shahzad, S., Afzal, A., \& Haider, S. (2019). Acute aluminum chloride toxicity revisited: Study on DNA damage and histopathological, biochemical and neurochemical alterations in rat brain. Life Science, 217, 202-211.

Lima, R. B., de Aguiar, C. L., Galaverna, R., Baptista, A. S., Eberlin, M. N., \& Arthur, V. (2016). Sucrose and color profiles in sugarcane (Saccharum sp.) juice analyzed by UFLC-ELSD and Synapt High-Definition Mass Spectrometry during radiation treatment. Radiation Physics and Chemistry, 121, 99-105. http://dx.doi.org/10.1016/j.radphyschem.2015.12.022

Machado, R. M. D., \& Toledo, M. C. F. (2006). Sulfite in foods. Brazilian Journal of Food Technology, 9(4), 265-275.

Machado, R. M. D., Toledo, M. C. F., Almeida, C. A. S., \& Vicente, E. (2008). Analytical determination of sulphites in fruit juices available on the Brazilian market. Brazilian Journal of Food Technology, 11(3), 226-233.

Mandro, J. L., Magri, N. T. C., Sartori, J. A. S., \& Aguiar, C. L. (2017). ICUMSA color reduction in concentrated raw sugar solutions by oxidative process with hydrogen peroxide. Brazilian Journal of Food Technology, http://dx.doi.org/10.1590/1981-6723.11416

Manenti, D. R., Módenes, A. N., Soares, P. A., Boaventura, R. A. R., Palácio, S. M., Borba, F. H., Espinoza-Quiñones, F. R.,

Bergamasco, R., \& Vilar, V. J. P. (2015). Biodegradability and toxicity assessment of a real textile wastewater effluent treated by an optimized electrocoagulation process. Environmental Technology, 36(1-4), 496-506. PMid:25182075.

http://dx.doi.org/10.1080/09593330.2014.952676

Martins, S. I. F. S., Jongen, W. M. F., \& van Boekel, M. A. J. S. (2001). A review of Maillard reaction in food and implications to kinetic modelling. Trends in Food Science \& Technology, 11(9-10), 364-373. http://dx.doi.org/10.1016/S0924-2244(01)00022-X

Mbanjwa, C. F., Deppa, N., \& Pillay, K. (2011). Evaluation of hydrogen peroxide at huletts refinery: preliminary results. International Sugar Journal, 113, 343-347.

Medeiros, J. K., Sarkis, J. R., Jaeschke, D. P., \& Mercali, G. D. (2021). Thermosonication for peroxidase inactivation in sugarcane juice. Lebensmittel-Wissenschaft und - Technologie, 140, 110730. https://doi.org/10.1016/j.Iwt.2020.110730.

Metrohm. (2019). Determination of aluminum by adsorptive stripping voltammetry. Application Bulletin, 131/3e, 1-5.

Miller, G. L. (1959). Use of dinitrosalicylic acid reagent for determination of reducing sugar. Analytical Chemistry, 31(3), 426-428. http://dx.doi.org/10.1021/ac60147a030

Minitab. (2021, January 29). Minitab Statistical Software (Trial Version). Retrieved in 2020, September 26, from https://www.minitab.com/en-us/support/downloads

Moradi, M., \& Moussavi, G. (2019). Enhanced treatment of tannery wastewater using the electrocoagulation process combined with UVC/VUV photoreactor: parametric and mechanistic evaluation. Chemical Engineering Journal, 358, 1038-1046. http://dx.doi.org/10.1016/j.cej.2018.10.069

Morilla, C. H. G., Alves, L. A. R., \& Aguiar, C. L. (2015b). Economic and financial feasibility analysis of sugarcane juice clarification: a case of sulfur dioxide replaced by hydrogen peroxide. Sugar Journal, 8, 17-20.

Morilla, C. H. G., Alves, L. R. A., \& Aguiar, C. L. (2015a). Process of clarification of sugarcane juice by sulfitation. Economic Review (Kansas City, Mo.), 24(1), 1-10.

Nguyen, D. M. T., \& Doherty, W. O. S. (2011). Phenolics in sugar cane juice: potential degradation by hydrogen peroxide and Fenton's reagent In R. C. Bruce (Ed.), Proceedings of the Australian Society of Sugar Cane Technologists Mackay, Queensland, Australia.

Nogueira, A. M. P., \& Venturini-Filho, W. G. (2007). Clarification of sugarcane juice by micro and ultrafiltration: proof of technical viability in preliminary experiments. Brazilian Journal of Food Technology, 10(1), 57-62.

Ogando, F. I. B., Aguiar, C. L., Viotto, J. V. N., Heredia, F. J., \& Hernanz, D. (2019). Removal of phenolic, turbidity and color in sugarcane juice by electrocoagulation as a sulfur-free process. Food Research International, 122, 643-652. PMid:31229123. http://dx.doi.org/10.1016/j.foodres.2019.01.039

Rafiee, P., Ebrahimi, S., Hosseini, M., \& Tong, Y. W. (2020). Characterization of Soluble Algal Products (SAPs) after electrocoagulation of a mixed algal culture. Biotechnology Reports, 25, e00433. https://doi.org/10.1016/j.btre.2020.e00433.

Rein, P. (2007). Cane sugar engineering. Berlin: Bartens.

Rodrigues, R., Sperandio, L. C. C., \& Andrade, C. M. G. (2018). Investigation of color and turbidity in the clarification of sugarcane juice by ozone. Journal of Food Processing Engineering, 41, e12661. https://doi.org/10.1111/jppe.12661.

Sartori, J. A. S., Angolini, C. F. F., Eberlin, M. N., \& Aguiar, C. L. (2017b). Criegee mechanism as a safe pathway of color reduction in sugarcane juice by ozonation. Food Chemistry, 225, 181-187. PMid:28193413. http://dx.doi.org/10.1016/j.foodchem.2017.01.028 
Sartori, J. A. S., Galaverna, R., Eberlin, M. N., Correa, N. T., Mandro, J. L., \& Aguiar, C. L. (2015). Elucidation of color reduction involving precipitation of non-sugars in sugarcane (Saccharum sp.) juice by Fourier-Transform ion cycloron ressonance mass spectrometry. Journal of Food Processing and Preservation, 39(6), 1826-1831. http://dx.doi.org/10.1111/jpp.12417

Sartori, J. A. S., Magri, N. T. C., Manarim, G. R., \& Aguiar, C. L. (2019). Impact of time between harvest and processing in sugarcane juice quality and effect of ozone in bacterial control of deteriorated juice. In Proceedings of the Brazilian Conference on Microbiology, Maceio, Brazil.

Sartori, J. A. S., Ribeiro, K., Teixeira, A. C. S. C., Magri, N. T. C., Mandro, J. L., \& Aguiar, C. L. (2017a). Sugarcane juice clarification by hydrogen peroxide: predictions with artificial neural networks. International Journal of Food Engineering, 13(2), http://dx.doi.org/10.1515/ijfe-2016-0199

Şengil, I. A., \& Özacar, M. (2006). Treatment of dairy wastewaters by electrocoagulation using mild steel electrodes. Journal of Hazardous Materials, 137(2), 1197-1205. PMid:16846691. http://dx.doi.org/10.1016/j.jhazmat.2006.04.009

Shi, C., Rackemann, D.W., Moghaddam, L., Wei, B., Li, K., Lu, H., Xie, C., Hang, F., \& Doherty, W.O.S. (2019). Ceramic membrane filtration of factory sugarcane juice: Effect of pretreatment on permeate flux, juice quality and fouling. Journal of Food Engineering, 243, 101-113.

Shi, Y., Wang, Z., Du, X., Gong, B., Jegatheesan, V., \& Haq, I.U. (2021). Recent advances in the prediction of fouling in membrane bioreactors. Membranes, 11, 381. https://doi.org/10.3390/membranes11060381.

Sillanpää, M., Ncibi, M. C., Matilainen, A., \& Vepsäläinen, M. (2018). Removal of natural organic matter in drinking water treatment by coagulation: A comprehensive review. Chemosphere, 190, 54-71. PMid:28985537.

http://dx.doi.org/10.1016/j.chemosphere.2017.09.113

Silva, W. S., Sartori, J. A. S., \& Aguiar, C. L. (2015). Combination effect of ozone and heat treatment for the color reduction in sugarcane juice. Chemical and Process Engineering Research, 35, 75-83.

Souza, F. L., Cotillas, S., Saéz, C., Cañizares, P., Lanza, M. R., Seco, A., \& Rodrigo, M. A. (2016). Removal of algae from biological cultures: A challenge for electrocoagulation? Journal of Chemical Technology and Biotechnology (Oxford, Oxfordshire), 91(1), 8287. http://dx.doi.org/10.1002/jctb.4580

Stahl, T., Taschan, H., \& Brunn, H. (2011). Aluminium content of selected foods and food products. Environmental Sciences Europe, 23(1), 1-11. http://dx.doi.org/10.1186/2190-4715-23-37

Syaichurrozi, I., Sarto, S., Sediawan, W. B., \& Hidayat, M. (2020). Mechanistic models of electrocoagulation kinetics of pollutant removal in vinasse waste: Effect of voltage. Journal of Water Process Engineering, 36, 103756. https://doi.org/10.1016/j.jece.2020.103756.

Tak, B. Y., Tak, B. S., Kim, Y. J., Park, Y. J., Yoon, Y. H., \& Min, G. H. (2015). Optimization of color and COD removal from livestock wastewater by electrocoagulation process: Application of Box-Behnken design (BBD). Journal of Industrial and Engineering Chemistry, 28, 307-315. http://dx.doi.org/10.1016/j.jiec.2015.03.008

Takahashi, M., Ishmael, M., Asikin, Y., Hirose, N., Mizu, M., Shikanai, T., Tamaki, H., \& Wada, K. (2016). Composition, taste, aroma, and antioxidant activity of solidified noncentrifugal brown sugars prepared from whole stalk and separated pith of sugarcane (Saccharum officinarum L.). Journal of Food Science, 81(11), 2647-2655. PMid:27780296. http://dx.doi.org/10.1111/17503841.13531

Tchamango, S., Nanseu-Njiki, C. P., Ngameni, E., Hadjiev, D., \& Darchen, A. (2010). Treatment of dairy effluents by electrocoagulation using aluminium electrodes. The Science of the Total Environment, 408(4), 947-952. PMid:19900696. http://dx.doi.org/10.1016/j.scitotenv.2009.10.026

Torres-Sánchez, A. L., López-Cervera, S. J., de la Rosa, C., Maldonado-Vega, M., Maldonado-Santoyo, M., \& Peralta-Hernández, J. M. (2014). Electrocoagulation process coupled with advance oxidation techniques to treatment of dairy industry wastewater. International Journal of Electrochemical Science, 9(11), 6103-6112.

Yousef, M. I., Mutar, T. F., \& Kamel, M. (2019). Hepato-renal toxicity of oral sub-chronic exposure to aluminum oxide and/or zinc oxide nanoparticles in rats. Toxicology Reports, 6, 336-346. http://dx.doi.org/10.1016/j.toxrep.2019.04.003.

$\mathrm{Vu}, \mathrm{T}$., LeBlanc, J., \& Chou, C.C. (2020). Clarification of sugarcane juice by ultrafiltration membrane: toward the direct production of refined cane sugar. Journal of Food Engineering, 264, 109682, https://doi.org/10.1016/j.jfoodeng.2019.07.029.

Zhang, Y., Shi, B., Zhao, Y., Yan, M., Lytle, D. A., \& Wang, D. (2016). Deposition behavior of residual aluminum in drinking water distribution system: effect of aluminum speciation. Journal of Environmental Sciences (China), 42, 142-151. PMid:27090705. http://dx.doi.org/10.1016/j.jes.2015.05.010

Funding: Ministério da Ciência, Tecnologia e Inovação/ Conselho Nacional de Desenvolvimento Científico e Tecnológico (506328/2010-4) and Fundação de Amparo à Pesquisa do Estado de São Paulo - FAPESP (2009/54635-1 and 2016/05123-1) 